\title{
On the Structure of Monsoon Lows over the Inland Area of Northern India
}

\author{
By Masato Murakami* \\ Meteorological Research Institute, Tokyo \\ (Manuscript received 22 September 1976, in revised form 19 April 1977)
}

\begin{abstract}
The mean vertical structure of monsoon lows over the inland area of northern India is investigated by the method of spectral analysis. It is compared with the result of Murakami (1976) in which the data of the station located on the coast of the Bay of Bengal are used. The structures of both stations show that the cyclonic circulation of monsoon lows prevails in the lower troposphere and their axis tilts slightly westward with height. They also bear warm-cored structure in common in the upper levels.

The most remarkable contrast appears in the field of specific humidity. When monsoon lows are in the vicinity of the Bay of Bengal, moistening occurs in coincidence with southerly winds, i.e. in the east of the trough. On the contrary, moist and cold anomalies appear in the west of the trough with northerly winds over the inland area. These contrasts suggest an intense geographic effect of Indian subcontinent on the life cycle of monsoon lows.
\end{abstract}

\section{Introduction}

In the analysis of summer monsoon fluctuations, Murakami** (1976) showed that the oscillation around 5 days period appears in northern India, corresponding to the passage of so-called monsoon lows. In his study, it is confirmed that monsoon lows propagate westward and their longi-

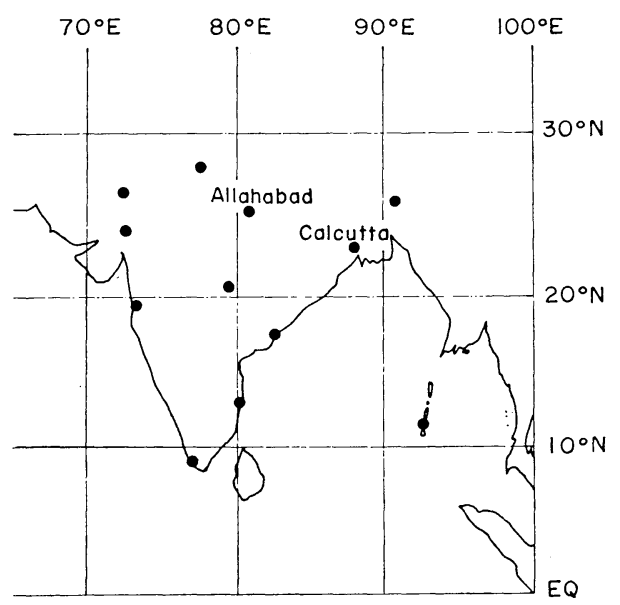

Fig. 1 Location of the observational stations.

* Present affiliation: Department of Meteorology The Florida State University, Tallahassee, Florida 32306.

** Hereafter referred to as $M$. tudinal wavelength is about $30^{\circ}$. He also showed their mean vertical structure based on the data of Calcutta which is located on the coast of the Bay of Bengal as exhibited in Fig. 1. However, as discussed immediately in the following section, the mean basic state of the atmosphere changes rather significantly when it comes into the inland area. This change as well as the topographic effect of the Indian subcontinent are likely to affect the structure of monsoon lows.

In this supplementary note, we intend to investigate their vertical structure over the inland area by using the data of Allahabad shown in Fig. 1. The period of analysis is the same as $M$, i.e., June through August, 1962. After that, we compare the vertical structure at Allahabad with the one at Calcutta obtained in $M$ and discuss the structural difference of monsoon lows between the oceanic and inland area.

\section{Mean resultant field}

In this section, we examine the horizontal distribution of the mean resultant fields and discuss their difference along the monsoon trough in northern India. Though the period of analysis extends for three months, the mean resultant fields of July are shown in this section. This month is presumed to bear the most intense monsoon activity and to show the typical situation of the monsoon season as the mean resultant 


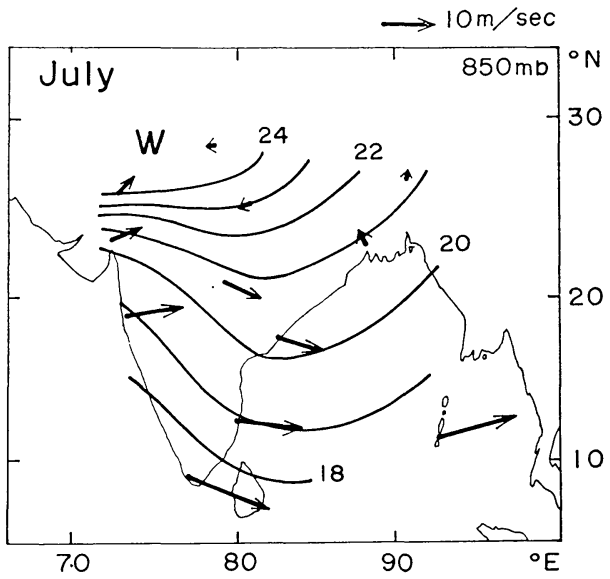

(a)

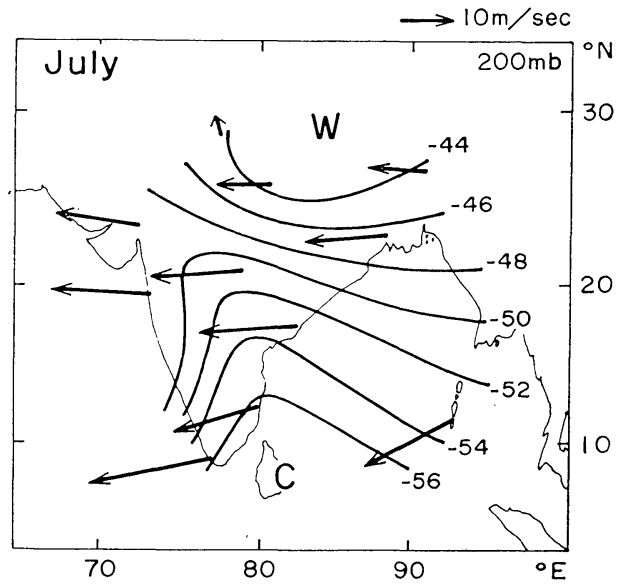

(b)

Fig. 2 Horizontal distribution of the mean resultant wind (arrows) and the temperature (solid lines; ${ }^{\circ} \mathrm{C}$ ), (a) at $850 \mathrm{mb}$ level and (b) at $200 \mathrm{mb}$ level.

field with the least distortion due to the seasonal trend.

Fig. 2 shows the horizontal distribution of the mean resultant wind and temperature both at the lower and upper levels of the troposphere. In the lower troposphere exhibited in Fig. 2a, monsoon westerlies prevail over the central and southern India, while the easterlies appear over northern India. The zone with cyclonic shear appears between these two wind regimes, corresponding to the monsoon trough. This zone lies roughly along $25^{\circ} \mathrm{N}$ and we can see that the southerly wind component is intensified near the head Bay of Bengal compared with the inland part of monsoon trough. In the upper troposphere shown in Fig. 2b, strong easterlies prevail over the whole
Indian subcontinent reflecting the easterly jet in the south of Tibetan high.

We can also see some longitudinal differences in the temperature field, though the gradient indicating northward increase of the temperature is outstanding throughout the lower and upper troposphere. In the lower troposphere shown in Fig. 2a, maximum temperature appears in the northwestern part of India reflecting the existence of surface heat low over the desert area. Between this area and the north Bay of Bengal, there exists the longitudinal temperature gradient. That is, the temperature increases toward the inland area along the axis of monsoon trough. In the upper troposphere shown in Fig. 2b, maximum temperature appears in the northern part of India near Himalayas in connection with the warm Tibetan high in the upper levels. This distribution at the upper level looks rather zonal over the monsoon trough region, though there exists obvious longitudinal contrast in the southern part of India between the Bay of Bengal and the Arabian Sea.*

The vertical stratification of the atmosphere also shows the difference between the coastal and the inland area. This difference is mostly due to the change of the vertical distribution of the atmospheric moisture. The situation is illustrated in Fig. 3 in which the vertical distribution of the

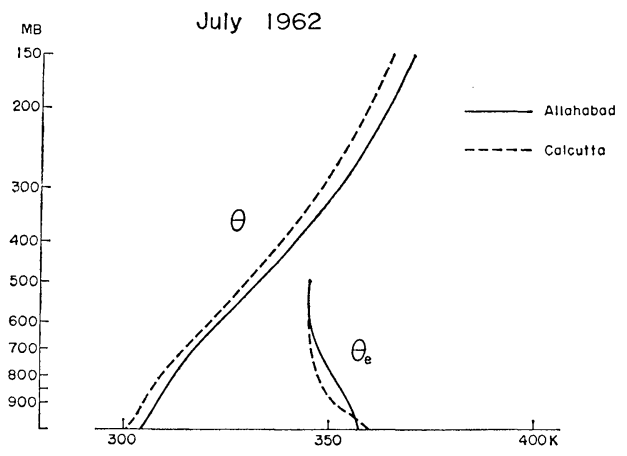

Fig. 3 Vertical distribution of the mean potential temperature $(\theta)$ and the mean equivalent potential temperature $\left(\theta_{e}\right)$ at Calcutta and Allahabad.

* We can see in Fig. 2 a that this contrast also appears in the lower troposphere. Besides, it is noteworthy that the longitudinal gradient is reversed when it comes from the lower into the upper troposphere. Recently, Mak (1975) referred to this gradient in his study of monsoonal mid-tropospheric cyclone. 
mean potential and equivalent potential temperatures are shown as to both stations of Calcutta and Allahabad. As for the profile of dry potential temperatures, both stations show similar profile apart from the difference of their absolute values. However, the moist equivalent potential temperatures show different stratifications between the two. Though both of them represent the existence of the conditionaily unstable layer in the lower troposphere in common, the conditional instability at Calcutta is more intense than Allahabad and is more concentrated in the lowermost layer below the $850 \mathrm{mb}$ level. The profile of equivalent potential temperatures at Allahabad represents that the instability is relatively weak and the unstable layer is broadened vertically in the lower troposphere. In other words, the vertical distribution of the equivalent potential temperatures becomes more uniform at Allahabad.

However, it is not assured yet at this stage using only two stations that the above difference actually comes from the contrast between the coastal and the inland area. In order to examine this problem, we define an index $I_{e}$ which represents the moist stability in the lowermost layer of the atmosphere as follows,

$$
I_{e} \equiv \frac{\theta_{e} 850-\theta_{e s}}{P_{s}-850} \times 100
$$

where $\theta_{e}, 850$ and $\theta_{e s}$ denote the mean equivalent potential temperature at the $850 \mathrm{mb}$ level and the surface, respectively. $P_{s}$ denotes mean surface pressure. By using this index $I_{e}$, the moist stability in the lowermost troposphere near the surface is examined over the whole Indian sub-

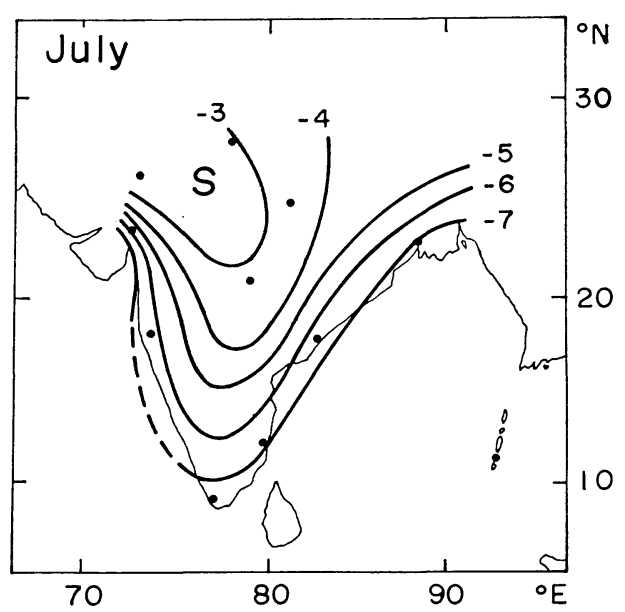

Fig. 4 Horizontal distribution of $I_{e}$ over India. $S$ denotes relatively stable area. continent. The results are exhibited in Fig. 4. This figure shows the horizontal distribution of the values of $I_{e}$ for July. Negative values represent the moist instability of the atmosphere below the $850 \mathrm{mb}$ level and their absolute values denote intensity. It can be seen in this figure that the values are distributed systematically and their absolute values decrease rather rapidly across the coast toward the inland area. Relatively most stable (least unstable) area appears over the northwestern India near Thar Desert. It is noteworthy that the relatively stable area also extends to the southern India behind the Western Ghats which range along the western coast of India. This region corresponds to the leeside of the mountains during the season of the monsoon westerly and is known as the semi-arid region during this period.

The results discussed above show that there exist some remarkable contrasts between the coastal and the inland area over northern India, especially in lower troposphere. They can be seen not only in the values of the temperature and the mean wind in horizontal domain, but also in the vertical stratifications of the lower atmosphere along the monsoon trough. These contrasts are likely to affect the monsoon lows propagating through this region. In the next section, we investigate their structure at Allahabad which is located in the inland area and compare it with the structure at the coastal area obtained in $M$.

\section{Structure of monsoon lows}

The method adopted in this section is the same as $M$ in which the vertical phase relationship and the power distribution are combined with the results of horizontal propagatability to construct the mean vertical structure. As revealed in $M$, the passage of monsoon lows appears at the oscillation around 5 days period. The spectral peak of this periodicity also appears at Allahabad rather intensively.

Fig. 5 represents the results of inter-level cross spectrum analysis at Allahabad for the period range 4.0 through 6.0 days. It shows the vertical distribution of the variances contributed by this period range and the phase differences of meridional wind relative to the $3 \mathrm{~km}$ level. It is seen in this figure that the variances of the meridional wind become small roughly above the $5 \mathrm{~km}$ level. The distribution of phase differences in time indicates the increase of phase with height, though the amount of increase is not very large. As discussed in $M$, monsoon lows propagate westward 


\section{$\checkmark 4.0-6.0$ DAYS}

Allahabad
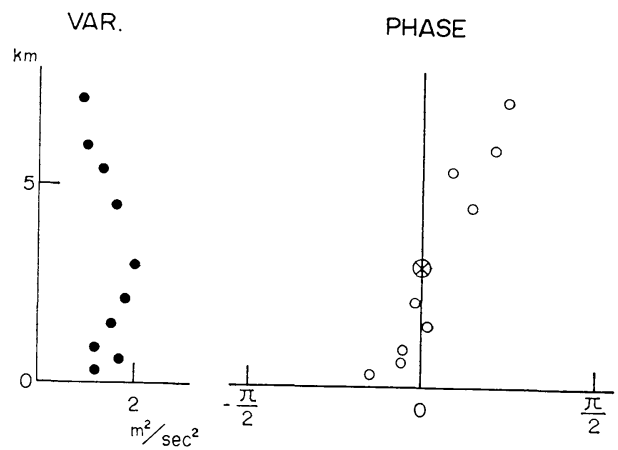

Fig. 5 Vertical distribution of the variances (left) and the phase differences relative to the $3 \mathrm{~km}$ level (right) of the meridional wind in the period range 4.0 through 6.0 days.

$4.0-6.0$ DAYS

Allahabad

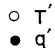

VAR

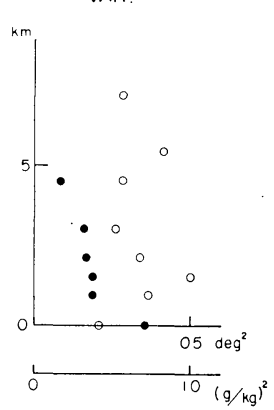

Fig. 6 Vertical distribution of the variances (left) of the temperature $\left(T^{\prime}\right)$ and the specific humidity $\left(q^{\prime}\right)$ and their phase differences (right) relative to the meridional wind $\left(V^{\prime}\right)$ at the same level.

through the monsoon trough region which includes Allahabad. Considering this with the result of vertical phase distribution mentioned above, it can be concluded that the axis of the disturbance in wind tilts slightly westward with height.

Fig. 6 represents the vertical distributions of the variances of temperature and specific humidity together with the result of inter-variable cross spectrum analysis between these variables and the meridional wind. It is remarkable that the distribution of the temperature variances shows two definite peaks in this area. One is around the $1.5 \mathrm{~km}$ level in the lowermost atmosphere and another peak appears at the upper level above $5 \mathrm{~km}$. The phase difference between the temperature and the meridional wind shows that the phase of the temperature relative to the meridional wind increases with height. It shows nearly $1 / 4$ cycle of phase lead in the upper levels, while these two are nearly in phase in the lowermost troposphere.

As for the oscillation of the specific humidity, the maximum variance appears at the surface and the value decreases with height. Its phase relative to the meridional wind shows somewhat large phase lead throughout the lower troposphere. Their values are larger than $1 / 4$ cycle and become nearly $1 / 2$ cycle (out of phase with meridional wind) at the surface. It means that the maximum anomaly of the specific humidity occurs in the regime of northerly wind.

Based on the results of the vertical version of monsoon lows discussed above, we can re-construct their mean vertical structure, in the same manner as done in $M$, when they pass over Allahabad. Fig. 7 exhibits thus re-constructed mean vertical structure in the left half and the structure at Calcutta discussed in $M$ in the right half. The abscissa denotes the phase difference in time relative to the passage of surface low. The vertical trough line was determined as the one where the meridional wind changes from the northerly to the southerly. Since we already know that monsoon lows travel westward as shown in $M$, we can interpret the positive phase difference (i.e. ahead of the lows) as westward direction and the negative phase difference as eastward. Hereafter, we shall discuss the vertical structure of monsoon lows based on the above interpretation.

In the vertical structure of the meridional wind at Allahabad shown in the upper-left part of Fig. 7 , we can see that the major cyclonic circulation occurs in the lower troposphere below the $5 \mathrm{~km}$ level. Its axis tilts slightly westward with height as discussed previously. On the other hand, the temperature anomalies exhibited in the lower left part represent that there exist two major amplitudes in the lower and the upper levels. In the lower levels, the warm anomaly occurs in the west, although the trough itself belongs to the relatively cold regime near the surface. However, the phase of the temperature relative to the meridional wind advances with height as shown in Fig. 6 so that the warm anomaly nearly coincides with the trough in the upper levels above $5 \mathrm{~km}$. This means that the monsoon lows at Allahabad also bear a warm-cored structure in 

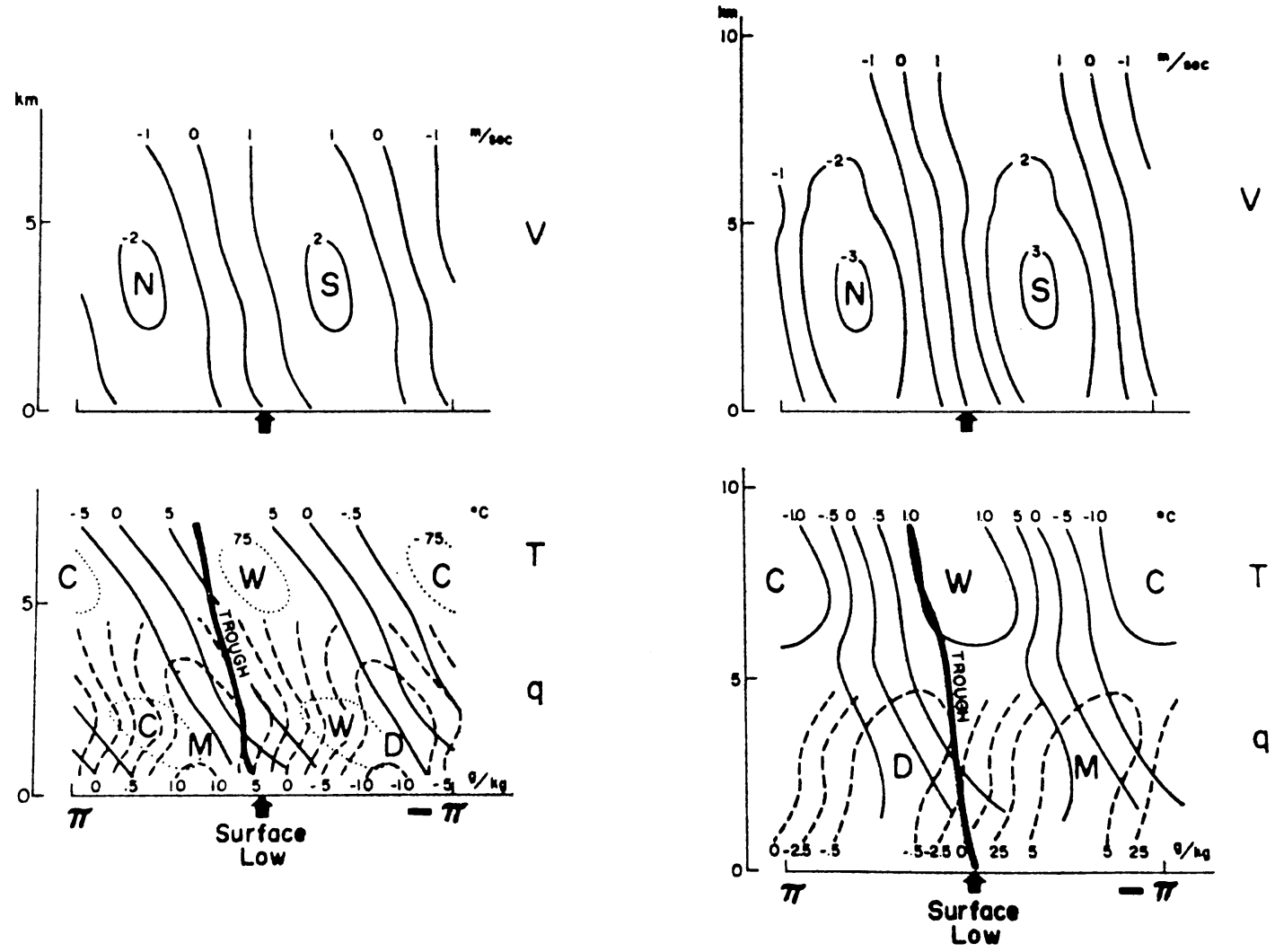

Fig. 7 Mean vertical structure of monsoon lows at Allahabad (left) and Calcutta (right).

these levels. The anomaly of the specific humidity shows its maximum amplitude at the surface. Moist anomaly takes place in the west of the trough in coincidence with the northerly wind. Dry anomaly occurs in the east with the southerly.

These configurations together with the vertical structure of the meridional wind resemble well the composited structure of monsoon depressions obtained by Godbole (1977). In his work, it is shown that the cyclonic circulation associated with depressions is confined in the lower troposphere below the $400 \mathrm{mb}$ level and its axis slightly tilts westward in the longitude-height plane. $\mathrm{He}$ also showed that the very moist regime takes place ahead of the depression, i.e. in the west of the trough. In addition, he obtained a very definite cold-cored structure in the lower troposphere and a warm core in the upper levels, being similar to the results obtained in the case study by Krishnamurti et al. (1975). In this work, however, the cold core in the lower troposphere is not very obvious with monsoon lows, though they bear a warm-cored structure in the upper levels. As discussed in $M$, this discrepancy seems to reflect the difference between the monsoon depressions which develop about 1.8 times per month and the relatively weak monsoon lows with 4 to 5 days periodicity.

As discussed previously, the mean vertical structure at Calcutta shown in the right half of Fig. 7 can be regarded as the one when monsoon lows are in the vicinity of the Bay of Bengal. By comparing this with the left half of the figure, we can see whether any significant change takes place during their propagation from the Bay into the inland area, though the data above $9 \mathrm{~km}$ level at Allahabad are not available due to the large amount of missing observations.

First, we can see that the vertical structure of the meridional wind does not change through its propagation. The cyclonic circulation prevails in the lower troposphere below the $5 \mathrm{~km}$ level at both stations and the both show that their axes tilt westward with height. However, the intensity of the cyclonic circulation reduces from the magnitude of $3 \mathrm{~m} / \mathrm{sec}$ at Calcutta to $2 \mathrm{~m} / \mathrm{sec}$ at Allahabad, reflecting the decay of monsoon lows during their propagation into the inland area. 
The most outstanding contrast appears in the configuration of the moisture field. At Calcutta, moist anomaly takes place in the east of the trough in coincidence with the southerly wind blowing from the Bay of Bengal. On the contrary, the moistening occurs in the west of the trough in case of Allahabad. In the vertical structure over this inland area, it can also be seen that the temperature anomaly has a major amplitude near the surface in addition to the upper warm core. Thus, the relatively moist and cold regime appears in the west of the trough in coincidence with the northerly wind and vice versa in the east of the trough. It is also noteworthy that the amplitudes of these thermal variables near the surface are rather intensified in the inland area in spite of the decay of the cyclonic circulation compared with the one at the coastal area.

\section{Remarks}

In this study, we discussed the horizontal distribution of the mean basic state of the atmosphere and made analysis on the vertical structure of monsoon lows over the inland area of northern India. As for the distribution of the mean basic state, we can see some remarkable differences along the monsoon trough. Though the detailed discussions are not repeated here, it should be noted that this situation contrasts with that of ITCZ in the Pacific or Atlantic in which the approximation of zonal symmetry can be applied as the mean basic state for the synoptic-scale disturbances.

Based on the recognition of the differences mentioned above, we analyzed the structure of monsoon lows over the inland area and compared it with the one over the coastal area obtained by $M$. Some contrasts as well as similarities are revealed as results. As for the kinematic field, nearly the same structure is maintained throughout its propagation from the coastal into the inland area, though the amplitude of cyclonic circulation is reduced according to the decay of monsoon lows. This structural consistency supports a posteriori the method of horizontal cross spectrum analysis applied to the meridional wind component by $M$ in order to estimate the horizontal wavelength of monsoon lows. Unless nearly the same structure is maintained throughout the propagation, this method is likely to lead to the misunderstanding about their horizontal scale.

The comparison of temperature fields revealed that monsoon lows bear warm-cored structure in the upper levels throughout their propagation. On the other hand, the secondary peak of the amplitude appears near the surface when monsoon lows are in the inland area, showing the warm anomaly in the east of the trough and the cold anomaly in the west.

The most remarkable contrast takes place in the field of specific humidity. When monsoon lows are located near the head Bay of Bengal, the moist anomaly occurs in the east of the trough in coincidence with the southerly wind from the Bay. This seems plausible when the consider the existence of very moist air-mass over the Bay of Bengal. On the contrary, moist anomaly appears in the west of the trough when they proceed into the inland area. This configuration is, however, consistent with our knowledge that the rainfall associated with monsoon lows and depressions occurs ahead of the trough (i.e. in the west of the trough in the longitude-height plane) when they pass through the inland area of northern India.

Considering above results together with the fact that the upward motion occurs in the west of the trough as revealed by Godbole (1977) and Krishnamurti et al. (1975), it is very likely that the convective activity associated with monsoon lows is also well-defined in the west of the trough when they are located in the inland area. But, the situation seems to be different when they are in the vicinity of the Bay of Bengal. The advection of moist air-mass from the Bay and a large amount of latent heat supply from the sea surface are expected when the lows are in the head Bay or in the vicinity of it. Besides, the lows do not receive such a great deal of the large-scale topographic effect in the oceanic area as they do when they pass through the inland area. All these contrasts are likely to affect the configuration of major convective activity as well as its intensity and consequently lead to the different field of thermal variables as exhibited in Fig. 7. According to these differences, it is also likely that the energy budget of monsoon lows shows difference between the two areas.

The results of this study discussed above claim the sufficiently dense observation network over the north Bay of Bengal as well as the inland of India in order to investigate the whole life cycle of monsoon lows and depressions. The forthcoming MONEX (Monsoon Experiment) is expected to provide a valuable opportunity to examine above-mentioned problems. 


\section{Acknowledgments}

The author wishes to express his thanks to Prof. T. N. Krishnamurti for his stimulative discussions and valuable comments. The author is also indebted to Mrs. C. Yata for drafting all the figures and to Mrs. Janina Richards for typing the manuscript. The research was partly supported by the National Science Foundation under NSF Grant No. ATM 75-18945.

\section{References}

Godbole, R. V., 1977: The composite structure of monsoon depression. Tellus, 29, 25-40.

Krishnamurti, T. N., M. Kanamitsu, R. Godbole, C. B. Chang, F. Carr and J. H. Chow, 1975: Study of a monsoon depression (I), Synoptic structure. J. Meteor. Soc. Japan, 53, 227-240.

Mak, M. K., 1975: The monsoonal mid-tropospheric cyclogenesis. J. Atmos. Sci., 32, 2246-2253.

Murakami, M., 1976: Analysis of summer monsoon fluctuations over India. J. Meteor. Soc. Japan, 54, 15-31.

\title{
北インド内陸部における Monsoon Low の構造
}

\author{
村上勝 人 \\ 気像研究所 \\ (現所属先 : フロリダ州立大学気象学教室)
}

スペクトル解析の手法を用い，北インド内陸部に拈ける monsoon low の平均垂直棈造佊調査した，結果を先に 著者によって求められたベンガル湾沿岸部での構造と比較して論じる。沿岸部, 内陸部とも low に伴なら低気圧性 循環は対流圏下部で卓越し，その軸は高さとともにやや西に傾いている。また両者ともとの上部に warm core を伴 なら。

一方, 最も湿著な相異は比湿の分布にあらわれる。low がベンガル湾近傍にある時, 湿潤な場は南風に伴なってト ラフの東にあらわれるが，内陸部では寒冷な北風に伴ないトラフの西にあらわれる。これらの相異は monsoon low のlite cycle に対するインド亜大琡の地理的影響の重要さを示唆しているよらである。 